Pakistan Journal of Education

Vol.38, No.2, 2021, 59-75

\title{
Gender Representation in Education: Critical Discourse Analysis of Urdu Textbooks used in Primary Government Schools in Punjab
}

\author{
Munaza Hasan Nasir ${ }^{*}$
}

\begin{abstract}
This research aims to explore the gender equality or lack thereof in the Urdu textbooks taught in Punjab, Pakistan. Gender bias in textbooks is an important but invisible and overlooked problem. Five Urdu textbooks taught in primary government schools in Punjab were selected for critical discourse analysis. Both qualitative and quantitative research methods were employed. The number of female and male characters, portrayal of domestic and professional roles by both genders, and cosmetic bias was taken into account. In all five books analyzed, 28\% characters were women whereas remaining were male characters. Female characters were mostly found in domestic situations with insignificant roles in the stories who did not have a name or an identity except being mothers. The text was highly biased towards the male characters associating valor and strength with men only. Since textbooks play a crucial role in the development of the children, it is important to remove the concealed gender bias in textbooks and acknowledge the changing roles of women in the Pakistani society in order to create a society that treats men and women equally.
\end{abstract}

Keywords: gender, education, textbooks, Urdu, women representation

\footnotetext{
Lahore School of economics. Email: munzak2014@gmail.com
} 


\section{Introduction}

The Academy of Educational Planning and Management (AEPAM) reported, "Out of the total 51.53 million children between the age of five and 16, around 22.84 million children (44\%) were out of school in Pakistan in 2018" (Dawn News, 2018). According to the official website of UNESCO, "In Pakistan, for every 100 boys only 86 girls are enrolled in primary school." The World Bank report on elementary education in Pakistan (1995) lays emphasis on the importance of improving quality of education to increase the number of students who enroll in schools.

Patriarchy is well-rooted in Pakistani society and gender bias is implicitly and explicitly present within the society. This study will explore the extent of gender bias prevalent in the Urdu textbooks used in schools in Punjab, Pakistan.

Gender bias in textbooks is an important but almost invisible and overlooked problem. More than a decade ago Ullah's research in Khyber Pakhtunkhwah concluded, "Textbooks give a clear message that women have a subsidiary status in society, their only appropriate and legitimate role is to perform the household tasks of nurturing and caring for the family" (Mattu \& Hussain, 2004; Ullah, 2007, p. 188). Textbooks can be seen as the opportunity to eliminate the existing gender disparity in Pakistani society (Malik \& Courtney, 2011).

\section{Aim of the Research}

The aim of the research is to evaluate Urdu textbooks used in primary government schools in Punjab and identify gender bias, if any, in these textbooks. Students spend a significant 80 to $95 \%$ of their time in classroom reading textbooks and teachers base majority of the classroom instruction on the textbooks (Sadker \& Zittleman, 2007). Hence, any hidden biases in the textbook should be revealed in order to eliminate gender bias from the society. Blumberg (2008, p. 345) found that gender bias "involves nearly identical patterns of under-representation of females, plus stereotypes of both genders' occupational and household roles that overwhelmingly underplay women's rising worldly importance." The aim of this research will be to identify if such issues exist in the Urdu textbooks of Punjab.

The researcher aims to analyze the content of Urdu textbooks prescribed by the Punjab Board of education. Books taught from Grade 1 to 5 were used for analysis. These years are formative years of children. Textbooks have an important role to play in shaping the students' minds 
(Loan, D. T., 2010, p. 5). Therefore, it is essential to explore the gender biases that exist in the textbooks used in the Pakistani government schools.

\section{Research Questions}

1. How are women and girls represented through text and images in the Urdu textbooks used in elementary schools in Punjab as compared to the men and boys?

2. What kind of roles and characteristics are associated with women and girls in Urdu textbooks used in primary schools in Punjab?

\section{Literature Review}

Language is not merely a mode of communication, but it has a "dialectical relationship with the society" (Fairclough, 2015, p. 19). Language influences the way people think and helps construct ideologies. Fairclough insists that "ideologies exist in texts and focuses on the argument that the interpretation of discourse may generate different ideological significance" (Fairclough, 1992, p. 89). "Whenever people speak or listen or write or read, they do so in ways which are determined socially and have social effects" (Fairclough, 2015, p. 56). It is therefore, important to identify the biases that exist in the textbooks because the text not only reflects the existing gender bias in the society but it also propagates it in the society.

Schools have a huge impact on learners and the society. Stromquist, Lee and BrockUtne (1998, p. 83) state that:

Educational institutions are powerful ideological institutions that transmit dominant values, and function as mechanism of social control... schools transmit values that not only reproduce social class but also maintain gender structures...the formal school system contributes to the reproduction of gender inequalities through such mechanism as ... the content of what is being taught and what is not ... and the kinds of knowledge men and women (and boys and girls) get.

It is evident that the content being taught plays a significant role in reproducing gender disparity and widening the gender gap that exists in the society. Textbooks play an important role in shaping up the personalities of the students. For students and teachers, textbooks are authorities. According to Stromquist et al, 
textbooks can easily become vehicles for promoting biases, including gender biases. They have lasting impression on the students' minds (Stromquist et al., 1998). Throughout history, in addition to being a source of entertainment, stories have propagated cultural values and norms (Peterson \& Lach, 1990).

In Pakistani schools, assessment is based on the rote memorization of the content. In such situations, the impact of the textbook content can be profound and everlasting. In order to promote gender equality and open mindedness textbooks used in schools should be analyzed and the content should be inclusive of all genders.

Pakistan is the signatory of Education for All (EFA), the aim of which was to ensure gender equality by the end of 2015. One of the goals of the ministry of education was to "eliminate gender bias in textbooks and curriculum" (Ministry of Education, 2003). However, previous studies conducted by Zafar (2005), Ullah (2007), and Jabeen (2014) indicate similar results that reflect gender bias in all textbooks taught in various provinces of Pakistan.

Blumberg (2008, p. 347) observed, "women were accommodating, nurturing drudges at home and in the few instances they were depicted at work it was in traditional activities; girls were passive conformists, while boys and men did almost all the impressive, noble, exciting and fun things and almost none of the caring, or 'feminine' acts or jobs."

Many researchers have argued that texts play a vital role in instilling gender-based values in children (Sunderland, 2001; Youdell, 2005). "The gender imbalance to which school children are introduced from an early age at home is reinforced in schools through the school curriculum" (Mugumya, 2004, p. 5). Therefore, it is essential that the resources used in schools are in line with the EFA goals of Pakistan.

\section{Methodology}

In Pakistan, every province has its own curriculum; hence books used in the government schools are different in every province. According to Alif Ailaan in Pakistan, 38\% children are enrolled in private schools and $62 \%$ are enrolled in government schools (Alif Ailaan, 2014). Since majority of the children go to government schools, this research focuses on the government schools' curriculum. This study is the first step of critical analysis of the Urdu textbook in particular. This research is limited to primary textbooks of Punjab, Pakistan.

The study employs both qualitative and quantitative methodology. Through purposive sampling, five Urdu textbooks used from classes 1-5 by the Punjab Board were studied and the content was critically analyzed. 
The books used in Grades 2 and 3 are written by Tahira Nasir, Sadia Seema, and Sadia Adeeb. Grade 4 Urdu textbook is written by two male authors, Nazeer-un-Balwi and Abdul Rehman Khan. The textbook used in Grade 5 is written by Dr. Ayub Nadeem and Tabinda Siraaj. For Grade 1 the name of the writers is not mentioned. Instead, it states that panel of experts in education has written the book.

A total of 73 lessons was studied in all textbooks. These lessons do not include poetry; only prose was studied because the poems in these books were either about animals or abstract concepts. Only women, men, boys and girls were taken into consideration. The number of important characters assigned to females and males was calculated. The quantitative analysis can be divided into three major categories: 1) main characters, male or female 2) supporting characters; male or female 3) biography of male or female characters.

Qualitative analysis was carried out by identifying several social themes. Only the number of roles played by males and females is not sufficient; the type of roles assigned to these genders is just as important because subtle messages are hidden in the text. The roles were categorized into two major roles: domestic and occupational.

Domestic roles assigned to men and women were studied. Interaction between males and females in domestic environment was analyzed. It was also observed whether men and women had equal opportunities to express their opinions. Occupational roles that can be carried out by men and women were analyzed. The kind of occupation that women and men have been assigned was counted in terms of frequency of occurrence. The kind of occupation open to both genders was also noted. The types of characteristics associated with male and female characteristics were also taken into consideration.

Blumberg (2008) has identified certain types of gender biases in textbooks. These biases include cosmetic bias and stereotyping. Cosmetic bias is explained by Blumberg as "things seemed to have been 'corrected'/'improved' in books, but bias persists in different ways". Stereotyping encompasses 'unfair assignment of characteristic to a group at the cost of individual attributes and differences.' Such biases were also identified in the text.

\section{Discussions}

In all five books analyzed, there were 210 characters including the main characters and the side characters. Out of these females were mentioned fifty-nine times (28\% of the characters) and male characters occurred 151 times. A total of thirty-six professions were mentioned in all 
five books. Out of these, all thirty-six professions were male occupations and three of these occupations were also associated with females. In all five books it was observed that the content is egregiously male biased.

\section{Cosmetic Bias}

According to Blumberg, cosmetic bias can be identified when the changes are superficial, and the bias is camouflaged. For example, in textbooks there are female characters, but they have been assigned secondary and supportive roles only. Out of the 210 lessons studied, $72 \%$ of the characters (main and supporting characters) are males and 28\% of the characters mentioned are females. It is, however, important to note the kind of roles that women characters have in the text mentioned are far less significant than the roles of male members. Majority of the female characters are 'fillers' who have no significant roles and are merely present passively listening to someone else speaking or observing what other characters are doing. These roles are so insignificant and small they may not be referred to as secondary roles. They are much smaller than secondary roles; hence 'fillers' is the more appropriate term. On the other hand, the male members are important figures in the society like the founder of the country, a caliph, a soldier, or a martyr. Therefore, the count of the female characters is misleading because female representation is far less than the number of female characters mentioned.

Table 1

\begin{tabular}{lccc} 
Gender of characters & & \\
\hline Book & Lessons & Male & Female \\
\hline Book 1 & 8 & 8 & 7 \\
Book 2 & 14 & 31 & 13 \\
Book 3 & 19 & 28 & 14 \\
Book 4 & 17 & 45 & 17 \\
Book 5 & 15 & 39 & 8 \\
Total & 73 & 151 & 59 \\
\hline
\end{tabular}

In textbooks for Grade 1 to 4 there is a picture of a boy and a girl on alternate pages at the top of the page. The number of pictures of boys and girls is the same but the text inside does not support this superficial cosmetic effort. As seen below, in text studied men occupy all the professions and are dominant in every field of life from a servant to a king. Thirty-six professions are associated with men whereas, women occupy only three professions namely doctor, teacher, and an inventor. Although, entire chapters are dedicated to the male characters, only half a sentence is dedicated to the woman who invented the compass. The role of the 
female teacher is relatively significant and there is a complete story about the female doctor. In fact, this is one of the 4 lessons out of 73 lessons that has an adult female as the main character.

\section{Biographies}

The biographies are about the founder of the country, the national poet, Prophet Mohammad, and two soldiers who sacrificed their lives for their country. These are all important figures in history of Pakistan. Male students have role models for inspiration.

Mohammad Ali Jinnah's biography appears in three out of the five books studied. Eight out of ten biographies are of male members. 20\% of the biographies are of women. The only biographies about women are of Fatimah Jinnah, sister of Mohammad Ali Jinnah and Hazrat Khadeeja, wife of the Prophet Mohammad (PBUH). Hazrat Khadeeja was a prominent businesswoman in sixth century who employed the prophet to assist in her business and Fatimah Jinnah was an active politician who was a presidential candidate in 1965 election of Pakistan. These facts are not mentioned in the lessons. These important historical characters are shown as caring wife and sister only.

\section{Characters and their Occupational Roles}

Out of the 27 times women were mentioned (not including girls), women were fulfilling the role of mothers 13 times. Mothers come in for a few lines in the stories to wake up the child in the morning, serve juice or perform insignificant roles that could have been fulfilled by any other character. Males were mentioned as fathers eight times out of 112 times (7\%). Fathers had more significant roles where they were driving and taking the family to see a salt mine or in another story the knowledgeable father talked about the solar system. Mother was not seen as conveying some valuable knowledge to the children. This conveys a message to the young learners that mothers do not have enough knowledge about the world to pass on to the children and it is their father who can convey knowledge of the world. The moral stories are passed on from grandmothers to the children. This does not reflect the real situation in the society where mothers are seen playing active role in their children's lives.

Occupational stereotyping is evident by analyzing quantitatively the professions associated with men and women in 73 lessons. Men have been mentioned performing paid jobs outside the house 36 times. On the other hand, only three professions were associated with women: doctor, teacher, and inventor. One whole lesson was about the mother who is a doctor; the 
teacher was mentioned in a few lines in three lessons; and only the name of the female inventor was mentioned in the lesson. The lesson about the female doctor is titled, "Why is Mom a doctor?" The daughter is upset that her mother who is a doctor is not available after school whereas all her classmates spend time with their mothers.

Table 2

Frequency of occupations filled by males and females

\begin{tabular}{lll}
\hline Male & Profession & Female Profession \\
\hline 1. & King & Doctor \\
2. & Caliph & Teacher \\
3. & Sultan & \\
4. & President \\
5. & Founder of the nation & \\
6. & Vizir & \\
7. & Prophet & \\
8. & Soldier & \\
9. & Philanthropist & \\
10. & Doctor & \\
11. & Inventor & \\
12. & Poet & \\
13. & Teacher & \\
14. & Cook & \\
15. & Servant & \\
16. & Farmer & \\
17. & Shepherd & \\
18. & Milk vendor & \\
19. & Barber & \\
20. & Tailor & \\
21. & Mail carrier & \\
22. & Carpenter & \\
23. & Cobbler & \\
24. & Architect & \\
25. & Mason & \\
26. & Mechanic & \\
27. & Electrician & \\
28. & Driver & \\
29. & Conductor & \\
30. & Confectioner & \\
31. & Gardener & \\
32. & Shopkeeper & \\
33. & Sportsperson & \\
34. & Tourist guide & \\
35. & Veterinarian & \\
36. & Ticket collector & \\
\hline
\end{tabular}

From the list of professions provided in Table 2, it is evident that the only professions women can occupy are the professions that require empathy and compassion. The professions served by men require analytical skills, 
bravery, power, and strength. In Grade 1 book, the young boys want to become soldiers and farmers and the young girls want to adhere to the traditional professions for women like a teacher and a doctor. Throughout the curriculum studied, men have the option to pursue any career whereas the females have limited options.

\section{Traditional Roles as Parents}

In the textbooks analyzed, women are seen fulfilling their domestic roles in majority of the stories. Their roles are a pale reflection of the role of women in Pakistani society. In the rural areas of the country, women work on the fields along with the men. This has been going on since decades and it is not a new phenomenon. However, in the textbook's women have been placed at home where they have no important role in the lives of their children, husbands, or any other relative. For example, in the lesson "Visit to Khewra Salt Range" when Saad (son) is curious about the origin of the salt, his father talks about the Khewra Salt Range. The father makes the plan to visit the Salt Range over the weekend and drives them to Khewra. The mother on the other hand comes into the picture when it is time to shop. She has no role to play until the last paragraph. She is happy and excited to buy the lamps made from salt (Grade 5 Textbook, Khewra Mine, p. 51).

In Grade 4 book there is a lesson called, "Why is My Mother a Doctor?" The title itself shows a negative attitude of the daughter towards her mother's career. The daughter was upset because all of her friends' mothers are at home when they come back from school, but her mother is not at home and she does not take her places. Zhang (2003) in his study found out that half of the Chinese middle school students surveyed did not like the fact that their mothers have a career. They preferred the traditional role of mothers namely, being a homemaker.

\section{Characteristics of Men and Women}

Men are brave, patriotic and can sacrifice their lives for the country. They have fought till their last breath in order to save their country. This can be seen across the board in all five textbooks in lessons like Major Aziz Bhatti, Tufail Muhammad Shaheed, National Flag, Minar-e-Pakistan to name a few (Grade 4 textbook).

In the second lesson, "Humanity and Kindness" (Khidmat-e-khalq Grade 5 textbook) during the fourteenth century, Usman Ghani, a rich and generous man, buys a well for twenty thousand Dirham and generously lets the people of the town get water from that well. Men are, therefore, 
not only strong and patriotic but they are also rich, generous and noble. Women on the other hand have no such role to play in the society. Throughout the course books most women are homemakers who do not earn money and are dependent on the male members of the society, mostly their husbands.

A boy sacrifices his Eid money (Grade 2 book, Eidi) so that a woman could buy things (The items are not specified in the book). This boy had been looking forward to Eid so that he could buy a toy plane. He is a kind and generous boy who gives money to the woman at the shop whereas the woman appears to be selfish, shameless, or maybe helpless who accepts money from a child. In an effort to teach children to be generous through the story of this boy, the writer completely ignores the unrealistic actions of the woman who accepts money from a child on Eid which is completely against the cultural norms of Pakistan.

\section{Nouns and Verbs}

In Urdu, the common nouns and pronouns used generally represent men. For example, jawanoun literally means youth but in Urdu this word always refers to young men. In the context it is used in lesson "Major Aziz Bhatti" (Grade 4 textbook) it means soldiers. The English word soldier can include male or female soldiers but the Urdu word jawanoun is a word used for men only. This automatically excludes women, and it inculcates in the students' minds that only men can be soldiers and precludes the option of girls dreaming to become soldiers and defending their country. According to UN report, "Use of a group character creates a group identity conducive to generalizations and the production and reproduction of stereotypes. An ungendered group, in addition to its collective identity, implies a mixture of men and women, which is often a factor of gender equality." A gendered group presented in the textbooks will promote gender disparity where it includes males and excludes females.

Mothers are referred to as $a m i$, which literally means mother. They have no names and no identities except being mothers of characters in the stories. Mason (2010) suggests names are our individual and collective identities. It is important to view the female characters out of the relational identities and view them as individuals with unique identities. Providing names to the individual not only enriches the content with information but also assigns significance to the character.

Unlike English, in Urdu verbs have a gender also. Two different words are used when a boy or a girl are performing the action. In the lesson 'Kabadi' (Grade 3 book), plenty of verbs are used and all these verbs are masculine. Some examples of the verbs mentioned are diya, jata, and 
saktay. If the girls were performing the actions these words would be deen, jateen, and sakteen, respectively. The girls are excluded from the text and male version of the verb is used. This implies that the sport is for boys only.

Similarly, the story (Grade 5, I Will Become a Scout) about scouts revolves around a boy who wants to become a scout. The girls are named girl guides. The title of the story in Urdu has the verb marked as a male (gaa). The image in this lesson is of a young man holding the Pakistani flag.

\section{Girls and Boys Represented in Sports}

Whereas boys dream of becoming boy scouts, girls are shown playing with fish in two out of the four stories in which the girls are main characters. The lesson "kabadi" is completely about boys. Kabadi is an indigenous game that is played in Punjab. As pointed out earlier, the nouns and verbs used are masculine in nature. Kabdai is a complex sport that requires strength and agility. Women are excluded from this sport. The girls are shown skipping rope and wearing bangles whereas the boy in the same picture is shown playing with a football.

\section{Images}

Images in textbooks play a vital role in gender construction, just like the written text. Images are also saturated with imbalance in gender representation. The number of pictures of the boys is much more than the picture of females since most stories/lessons are about male characters. Stereotyping is observed on the glossy cover page of Grade 4 book that has two girls and a boy (Appendix A Figure 1). On this page, a boy is playing football, while a girl is skipping rope and the other is reading a book. These are the typical pastimes associated with girls and boys. Grade 5 textbook has a picture of the poet Allama Iqbal and the male guard at his mausoleum. Other important pictures include picture of Mohammad Ali Jinnah, Major Aziz Bhatti and Tufail Mohammad Shaheed.

In one image Grade 4 (p. 146), the grandfather is sitting on the mat with his grandson and the granddaughter is bringing food. In another image in Grade 1 book (p. 83) in a speech bubble the boy is thinking who will give him breakfast since his mother is sick. Nowhere in the text or in the images a male character is shown performing domestic chores. This is in line with the Pakistani society where the girls are trained to do the house chores including chores for their brothers regardless of their age. 
Grade 5 book has fewer images than the previous grades. There are 12 images of male characters and three images of female characters. Pictures of females include Fatima Jinnah and in another lesson a girl staring at a fish in a bowl. In the third image the girl is riding a merry go round. Girls are seen restricted within domestic boundaries.

\section{Conclusion}

It can be concluded that men are substantially overrepresented in Urdu textbooks used in the primary schools of Punjab, Pakistan. Women and men are not equals and men have more power as compared to women. Akbar et al (2008) found similar trend in English fairy tales where mothers were shown as weak and fragile. Analysis of the textbooks based on the school year revealed that the number of male characters always exceeded the number of female characters in all the textbooks taught in primary schools regardless of the class. The number of images of the males was also significantly greater than the images of the females.

Millions of girls in Pakistan are out of school. The remaining girls who have access to education do not have any female role models they can identify with because female role models are almost non-existent in Urdu textbooks. There is a lack of women portrayed as public speakers, pilots, computer scientists, entrepreneurs, bankers, and myriads of other professions that women occupy in the real Pakistani society. Existing research suggests that students develop self-esteem and a sense of themselves in society when they see their "appropriately gendered role models" in books and other educational materials (Campbell, 2010).

Stereotyped gender roles were depicted in the textbooks. Women were seen performing their chores at home without much say in making decisions whereas males were seen as people in power and positioned in the public domain. This exacerbates the issue of male dominance in the Pakistani society. As a whole, Urdu textbooks do not have sufficient number of lessons about sports. The few lessons included in the books revolve around boys and exclude the girls. In Pakistan, women have a cricket team and a hockey team to name a few sports, but the textbooks do not show the real situation.

Pakistan is the signatory of Education for All (EFA), but no efforts have been made to fulfill this promise. A decade ago, research conducted by Ullah, Mattu and Hussain, in different provinces of Pakistan has shown gender inequality in the text. Although, this work does not focus on Urdu textbooks, but the results show the subordinate role of women promoted through English textbooks and under representation of women. After a decade, the issue remains the same and there is no improvement in the 
content of textbooks. The authors of the textbooks analyzed for this research include women, but these women have ignored the pervasive gender bias in these textbooks, or it may be assumed that these authors themselves are a victim of the educational system and they cannot identify gender bias in the stories included in the textbooks.

\section{Implications of the Research}

Previous research has not focused entirely on Urdu textbooks used in primary schools of Punjab. This research will focus only on Urdu textbooks. Urdu is the national language of Pakistanis, and it is the language that all the educated Pakistanis understand. English textbooks have stories borrowed from other cultures, but Urdu textbooks depict the Pakistani culture. Therefore, it is important to analyze the content in terms of portrayal of gender equality in Urdu textbooks that is culturally and linguistically relevant to the students.

\section{Recommendations}

It is not only important to eradicate male centered text, but it is equally important to portray a positive image of women in order to ensure a non-discriminatory education system. These lessons articulate the prevalent cultural and social norms in the Pakistani society where men are considered stronger and more productive than women.

It is necessary to create awareness and promote gender equality through the content in the textbooks. Textbooks should be modified in order to increase female representation. For a balanced view of the world, boys need some role models from the other gender. Therefore, it is not only necessary for girls to have female role models, but it is equally important for boys to read about female Pakistani role models.

Although, gender biased textbooks are a universal problem, it can be resolved. Sweden has been working towards gender equality in the society. Sweden has been working towards this goal for forty years and the results are visible now. They have updated the textbooks and curricula in order to achieve this goal (Blumberg, 2008). Pakistan can follow suit and bring about a change in the mindsets of people. Both men and women must achieve a balance of power and control.

The authors of the books should be more sensitive to the gender issues and try to achieve gender equality. Stories included in the textbooks should also talk about the exciting, adventurous, intelligent, generous, and noble women that Pakistan has produced. We have many accomplished women who can serve as the role models for the youth of Pakistan. These 
include the Nobel Prize winner Malala Yousafzai; Dr. Ruth Pfau who dedicated her life serving the poor; Bilquees Edhi who runs Edhi Foundation; and Shirmeen Obaid Chinoi (two times Oscar Winner) to name a few eminent women of the country. In the field of sports, Sana Mir, the captain of Pakistani women's cricket team has bagged two gold medals in the Asian Games in 2010 and 2014. The ministry of education should pay attention to the content being taught in the classroom and introduce text that promotes gender equality and eliminates gender disparity. 


\section{References}

Akbar, T., Malik, R. \& Azam, F. (2018). Gender issues in children's literature: An analysis of fairytales. Pakistan Journal of Education. 35 (1), 59-70.

Alrabaa, S. (1985). Sex division of labour in Syrian school textbooks. International Review of Education 31(1), 335. https://doi.org/10.1007/BF02262586

Ansary, H. \& Babaii, E. (2003). Subliminal sexism in current ESL/EFL textbooks. Asian EFL Journal, 5(1), 1-15. Retrieved July 14, 2019, from http://www.asian-efl journal.com/march03.sub1.php

Bahman, M. \& Rahimi, Ali (2010). Gender representation in EFL materials: an analysis of English textbooks of Iranian high schools. Procedia Behavioral and Social Sciences, 9, 273-277 https://doi.org/10.1016/j.sbspro.2010.12.149.

Blumberg, L. R. (2008). The invisible obstacle to educational equality: Gender bias in textbooks. Prospects. 38, 345-361. 10.1007/s11125009-9086-1.

Corbin \& Strauss (2008). Basics of qualitative research. Sage publications.

Fairclough, N. (1992). Discourse and text: Linguistic and intertextual analysis within discourse analysis. Sage Publications.

Fairclough, N. (2015). Language and power. London: Routledge

Jabeen, S. et al (2014). Gender Discrimination in Curriculum: A Reflection from Punjab Textbook Board. Bulletin of Education and Research. 36(1), 55-77

Kenneth, L. D. (1983). Names, identity, and self. Names. 31(4), 245-257, DOI: 10.1179/nam.1983.31.4.245

Leeu, J.F.K. \& Collins, P. (2009). Australian English-language textbooks: the gender issues. Taylor and Francis (https://doi.org/10.1080/09540250802392257) Routledge

Loan, D. T. et al. (2010). Guidelines for textbook review and analysis from a gender perspective. UNESCO Retrieved from https://docs.iiep.unesco.org/peic/2748.pdf 
Malik, A. B. et al (2015). Education for all 2015 national review report. UNICEF: Islamabad https://unesdoc.unesco.org

Mason, D. (1990). A rose by any other name...? Categorisation, identity and social science. Journal of Ethnic and Migration Studies, 17(1), 123-133, DOI: 10.1080/1369183X.1990.9976227

Mattu, M. \& Hussain, N. (2004). Gender biases and stereotypes in school text, the subtle subversion - the state of curricula and textbooks in Pakistan. Islamabad: Sustainable Development Policy Institute.

Mirza, M. S. \& et al (2003). Quality of primary education in Pakistan. Ministry of education. Retrieved 20 February, 2019 http://unpan1.un.org

Mugumya, L. (2004). How gender segregation at school undermines equal opportunities: a male viewpoint. Equals 4, a newsletter of the Beyond Access project: Oxfam and Institute of Education, University of London, 5-6.

Mustapha, A. S. (2012). Dynamics of gender representations in learning materials. Multidisciplinary Journal of Gender Studies, 1(3), pp. 243270.

Peterson, S. B. \& Lach, M. A. (1990) Gender Stereotypes in Children's Books: their prevalence and influence on cognitive and affective development, Gender and Education, 2(2), 185-197, DOI: $10.1080 / 0954025900020204$

Sadker, D. M. \& Zittleman, K. (2009). Teachers, schools and society: A brief introduction to society. McGraw-Hill Higher Education

Sunderland, J. (2001). Gendered discourses. London: Palgrave Macmillan

Taylor, A. \& et al. Gender equity in communication skill. Retrieved February 2019 from http://pages.uoregon.edu/

Ullah H. \& Skelton, C. (2013) Gender representation in the public sector schools textbooks of Pakistan, Educational Studies, 39(2), 183-194, DOI: $10.1080 / 03055698.2012 .702892$

UNESCO. (2004). Gender analysis of school curriculum and textbooks. Islamabad: UNESCO Retrieved from: www.un.org.pk/unesco

http://uis.unesco.org/en/news/international-womens-day-explore-latestuis-data-eatlas-gender-inequality-education. 
Youdell, D. (2005). Sex-gender-sexuality: How sex, gender and sexuality constellations are constituted in secondary school. Gender and Education 17: 249-270.

Citation of this Article:

Nasir, M. H. (2021). Gender representation in education: Critical discourse analysis of Urdu textbooks used in primary government schools in Punjab. Pakistan Journal of Education, 38(2), 59-75. 
